\title{
The Social Responsibility of State-Owned Enterprises (SOE) Through the Partnership Program with Micro, Small and Medium Enterprises (MSMEs)
}

\author{
Nurhaedah ${ }^{1} \quad$ Marthen Arie ${ }^{2} \quad$ Juajir Sumardi ${ }^{2} \quad$ Oky Deviani Burhamzah $^{3}$ \\ 1. Doctoral Student, Faculty of Law, Hasanuddin University, Indonesia \\ 2. Professor of Law, Faculty of Law, Hasanuddin University, Indonesia \\ 3. Associate Professor, Faculty of Law, Hasanuddin University, Indonesia
}

\begin{abstract}
Justice and welfare are the goals of national development, so the state must be present to protect and prosper its people, through State-Owned Enterprises (SOE) given social responsibility through the Partnership Program. This research is a normative legal research using a philosophical approach. The results of this study indicate that the essence of social responsibility of State-Owned Enterprises through the Partnership Program with Micro, Small and Medium Enterprises (MSMEs) is an effort to balance the interests of all parties. This balance of interests can only be achieved through certain regulatory mechanisms. Fulfillment of interests is carried out proportionally and in a balanced manner through regulatory mechanisms, namely through the use of funds originating from a net profit of no more than $2 \%$ (two percent), in the form of channeling funds for the Partnership and Development Program. both in the form of business capital loans as well as guidance and purchase of production support tools aimed at improving the quality of social life both for the company itself and for MSMEs which are implemented with the principles of fairness, balance, transparency and sustainability.

Keywords: Social Responsibility; State-Owned Enterprises (SOE); Micro, Small and Medium Enterprises (MSMEs).
\end{abstract}

DOI: $10.7176 / \mathrm{JLPG} / 109-05$

Publication date:May $31^{\text {st }} 2021$

\section{A. Introduction}

Article 33 of the 1945 Constitution of the Republic of Indonesia as a constitutional basis for business activities in achieving national development goals and the commitment of the nation is also a philosophical foundation in realizing justice and welfare for business actors, whether handled by the government or the private sector. $^{1}$ Through State-Owned Enterprises (hereinafter abbreviated as BUMN), they are given the responsibility, in addition to having an economic responsibility side to shareholders such as obtaining profits, they are also burdened with the responsibility to improve the welfare of Micro, Small and Medium Enterprises (abbreviated as MSMEs) through The Social Responsibility of BUMN through the Program Partnership.

The Partnership Program is a form of cooperation between SOE and MSMEs in principle to achieve one goal, namely to create an independent and resilient national economy. This Partnership Program is not only for the benefit of MSMEs but also for the benefit of the company itself. Regarding the social responsibility of BUMN through Partnership Patterns with Micro, Small and Medium Enterprises, the Government has issued several policies in the form of laws and regulations to empower MSMEs, which are regulated in Article 2 paragraph (1) Letter (e) of Law No. 19 of 2003, which explains that one of the aims and objectives of establishing SOE is to actively participate in providing guidance and assistance to economically weak entrepreneurs, cooperatives and the community. Article 88 paragraph (1) of Law No. 19 of 2003 also states that SOE can set aside a portion of its net profit for the purposes of fostering small businesses / cooperatives as well as fostering communities around SOE.

The implementation form of Article 2 and Article 88 of Law No. 19 of 2003 is the implementation of the Partnership and Community Development Program by all SOE. Article 1 number 3 Law No. 40 of 2007. In Article 1 point 3, it is explained that social and environmental responsibility is the Company's commitment to participate in sustainable economic development in order to improve the quality of life and a beneficial environment, both for the Company itself, the local community, and society in general. Thus, the social responsibility of SOE through the Partnership program, especially related to the Implementation of the Partnership and Community Development Program, has a clear legal basis.

Empowerment of MSMEs by SOE Companies is very important in obtaining coaching and providing

\footnotetext{
${ }^{1}$ In the last amendment, the naming of the national economy was added to Chapter XIV, Article 33 . That is the basic argument of the Indonesian economic constitution, in which there are principles and methods developed to run the national economy. Economic principles remain the basis of the economy, but the addition of economic democracy does not apply absolute equel treatment. Inserted the word efficiency justice is the embodiment of the ideals of economic democracy based on social justice for all Indonesian people, side with the weak. Swasono, S. E. (2002). Sistem Ekonomi Indonesia. Jurnal Ekonomi Rakyat.
} 
capital assistance through the Partnership Program, because MSMEs in Indonesia have proven able to withstand economic shocks and become saviors for the economy during the financial crisis in 1997 and the global crisis in 2008. The Ministry of Cooperatives and Small and Medium Enterprises stated that in 2014, there were around 57.8 million MSME players in Indonesia, in 2017 and in the next few years it is estimated that the number of MSME players will continue to grow. In addition to having a role in economic growth, MSMEs also absorb $99 \%$ of Indonesia's workforce, although the quantity is very large and absorbs a lot of labor, while the market share in national income is still around $57 \%{ }^{1}$

Data from the Ministry of Cooperatives, Small and Medium Enterprises in 2016 and 2017 shows that MSMEs have a very large role in the Indonesian economy. There are many advantages and contributions from MSMEs, the contribution of MSMEs to Indonesia's GDP in 2016 was 59.84\% and absorbed 97.04\% of the national workforce, while the contribution of MSMEs to Indonesia's GDP in 2017 was 60\% and absorbed $97.02 \%$ of the national workforce. Based on statistical reports on the number of Micro, Small and Medium Enterprises in 2016, it can be seen from the development of MSMEs consisting of 60,863,578 Micro Enterprises or $98.71 \%, 731,047$ or $1.19 \%$ Small Businesses, 56,551 or 0.09\% Medium Enterprises and Large Enterprises only 5,370 or $0.01 \%$. Meanwhile, the number of MSMEs in 2017 can be seen from the development of MSMEs consisting of Micro 62,106,900 or $98.90 \%$, Small Businesses 757,090 or 1.20\%, Medium Enterprises 58,627 or $0.09 \%$, while Large Enterprises are only 5,460 or $0.01 \%$. This proves that the absorption of labor and equal distribution of economic income for the Indonesian people relies more on the MSME sector. ${ }^{2}$

The problem faced by MSMEs is that the development of MSMEs has increased in terms of quantity, but has not been matched by an even increase in the quality of MSMEs. The classic problems faced are low productivity, this situation is caused by internal problems faced by MSMEs including low quality of MSMEs human resources, aspects of organizational management, mastery of technology, and marketing, weak entrepreneurship of MSME actors, and limited access of MSMEs to capital, information technology and market, as well as other production factors. ${ }^{3}$ Meanwhile, external problems faced by MSMEs include the large amount of transaction costs due to an unsupportive business climate and scarcity of raw materials, and the large number of products from abroad in Indonesia. Based on the results of the 2018 Institute for Management Development survey, the competitiveness of Indonesian workers is ranked 4th in Asean. This of course is no longer just a warning, but has become a serious threat, because the integration of the Asean Economic Community (AEC) is not limited to free trade, but also penetrates the labor market, if not immediately tidy up, the Indonesian labor market can be invaded by Singapore, Malaysia and Thailand, the causes include low education and the mismatch between education and the needs of the business world. The quality of workers determines productivity and global competitiveness, as evidenced by Indonesia's Global Competitiveness Index in The Global Competitiveness Report 2018 issued by the World Economic Forum (WEF), Indonesia is ranked 45th, while Indonesia's Innovation ability is ranked 68th, the next challenge Indonesia must be ready to enter the era of Industry 4.0, this not only requires the readiness of skilled labor and the intensity of high-cost research, especially when transfer or transfer of technology is difficult to expect from foreign investment, so Indonesia must prepare new and appropriate technology to determine business efficiency in winning. competition. ${ }^{4}$

In order to increase the dignity of MSMEs at both the national and international levels, SOE should help MSMEs to be able to face global economic challenges and reduce economic inequality between large and small businesses by implementing the Partnership Program as Social Responsibility. In addition, this Partnership Program is not solely for the benefit of MSMEs, but also for the interests of the company itself, this Partnership Program is a long-term investment that streamlines the production process of a company because it will lead to two-way communication between SOE companies and MSMEs, so this Partnership Program will raise the good name and image of the company in the eyes of the community.

In fact, the Partnership Program at SOE has been partially implemented, it's just that the program continues to be under the spotlight and criticism of some community groups and small businesses who have not enjoyed and felt the benefits of the Partnership Program, so it still feels uneven and fair. This occurs due to a lack of information and coordination on BUMN policies to community groups or small businesses related to planning and synchronization of existing programs. The Partnership Program of SOE still tends to choose its own targets, as a result the distribution of capital assistance, coaching, and others is still not evenly distributed in all sectors of Micro and Small Enterprises so that it has not been able to realize its capabilities and roles optimally in realizing MSMEs in a resilient and independent manner.

\footnotetext{
${ }^{1}$ Putra, A. H. (2016). Peran UMKM dalam Pembangunan dan Kesejahteraan Masyarakat Kabupaten Blora. Jurnal Analisa Sosiologi, 5(2). p. $40-52$.

${ }^{2}$ http://www.depkop.go.id/data-umkm, Accessed on 12 April 2019.

${ }_{3}^{3}$ Pelupessy, E., Sumardi, J., Marlang, A., \& Miru, A. (2015). Government's Role to Protect the Small Business of Local Communities Legally in Papua. JL Pol'y \& Globalization, 38, 14

${ }^{4}$ Enny Sri Hartati (Peneliti Senior Institute for Developmentof Economics and Finance), 2019, Harian Kompas on 16 Juli 2019 , p.1
} 


\section{B. Research Methods}

This study is a normative legal research using a Philosophical Approach. The collected data were analyzed qualitatively by interpreting, describing and arranging them systematically according to the research objectives.

\section{Result and Discussion}

The SOE, apart from having the main function of seeking profit, also has the duty to pay attention to social issues as regulated in Article 2 paragraph (1) letter (e) of Law No. 19 of 2003, which explains that one of the aims and objectives of establishing SOE is to actively participate in providing guidance and assistance to economically weak entrepreneurs, cooperatives and the community. Article 88 paragraph (1) of Law No. 19 of 2003 also states that SOE can set aside a portion of its net profit for the purposes of fostering small businesses / cooperatives as well as fostering communities around SOE. As an embodiment of Article 2 paragraph (1) letter e and Article 88 of the SOE Law, the Social Responsibility of SOE is implemented through the Partnership and Community Development program, and the latest provisions are regulated in SOE Ministerial Regulation Per-02 / MBU / 04/2020 concerning Third Amendment to SOE Ministerial Regulation Number Per-09 / MBU / 07/2015.

The Social Responsibility of SOE through the Partnership Program is the focus point for researchers, where the aim of the Partnership Program is to improve the welfare and ability of MSMEs to become resilient and independent because MSMEs are an integral part of the business world which is the people's economy which has a position, role and potential. strategic to realizing a national economic structure based on economic democracy so that the existence of MSMEs in Indonesia must receive attention from the government, especially from SOE.

MSMEs represent almost all business units in various economic sectors that live in our economy, because of their very large number, until now small businesses represent around $99.85 \%$ of the total number of business units, while Medium Enterprises are 0.14\% and Large Enterprises. only 0.01, thus the pattern of the Indonesian economy in terms of the legal subject of business actors is the people's economy consisting of small businesses in various sectors, especially the agricultural sector and trade as well as services and industry, so that in terms of position in supporting the economy, small businesses occupy a very strategic position because it accounts for more than $88 \%$ of employment. Position is very important to ensure macro stability, especially national stability, which has recently become very critical as a determinant of the continuity of economic growth and new investment to sustain growth. Economic sectors are driven by the people's economy so that MSMEs must continue to upgrade and be active in order to advance and compete with large companies.

The partnership program is a form of social concern for the community and is an empowerment and development program for Small, Micro and Medium Enterprises by The SOE, through the use of funds sourced from company profits with a maximum net of $2 \%$ (two percent). This partnership program is a program to increase the capacity of small businesses in the form of loans both for business capital and the purchase of production support equipment so that MSMEs can become resilient and independent. ${ }^{1}$

Corporate social responsibility through the Partnership Program is essentially to improve the quality of social life for both the company itself, the local community and for the community as a whole or MSMEs business actors, meaning that from the company's point of view, the use and value of benefits that can be obtained is to improve the company's image. as well as an effort to maintain the company's existence in order to operate in a sustainable manner. Meanwhile, from the stakeholder's point of view, in this case the MSMEs actors get the distribution of the value of benefits that have been received by the company to the community or MSMEs players, thus equitable distribution of benefit values can be realized, welfare increases and in the end the independence of MSMEs can be achieved so that reducing social disparities and furthermore, Social Responsibility through the Partnership Program is expected to provide maximum benefits for the realization of the people's prosperity in a just and equitable manner.

\section{The Implementation of Social Responsibility from SOE through the MSMEs Partnership Program is based on the Principles of Fairness.}

The company of SOE as one of the components of society develops a constitutional duty to create welfare for all Indonesian people fairly and equitably. The objective of implementing social responsibility is essentially an effort made by the company to fulfill its constitutional duties, namely to participate in realizing the greatest prosperity of the people. This is the basis, why every SOE is obliged to carry out social responsibility, without any differences between SOE operating in the production sector managing natural wealth potentials and SOE engaged in the service sector. So it can be understood that in the context of a welfare state, ideally the implementation of Social Responsibility is not only oriented towards fulfilling the interests of stakeholders or merely seeking benefits for shareholders. However, it is further than that, namely to create prosperity for all people in a just and equitable manner.

\footnotetext{
${ }^{1}$ Fajar, M., \& Setyaningrum, R. B. (2017). Pelaporan Program Kemitraan dan Bina Lingkungan serta Corporate Social Responsibility Badan Usaha Milik Negara. Jurnal Media Hukum, 24(2), 193-206.
} 
The view stated above is a reaction to a challenge to the understanding developed by the teachings of Neo Capitalism, which has an attitude and opinion, that the only responsibility of the company is to seek the maximum profit to be distributed to shareholders. The company's responsibility is limited to meeting the interests of the shareholders. Social responsibility, including the responsibility for the welfare of the people and environmental protection, is not the responsibility of the company but is the responsibility of the government. The teachings of Neo-capitalism or Neo-liberalism have resulted in the development of the Company that is inhuman and unfair because it only makes profits without paying attention to the misery of society and the damage to the surrounding environment.

This teaching is opposed by moralism, because it is not only the shareholders who are the company's stakeholders, but the people around the company's activities are also stakeholders. Therefore, in addition to complying with all laws and regulations, the company is also responsible for social and environmental problems. This means that the company's stakeholders are not only limited to shareholders, employees, or employees and laborers, but also members of the community. Thus, the company not only pays attention to the interests of shareholders, employees and workers who work for it but also must pay attention to the community and the surrounding environment. Certainly, it is impossible for a company to pay attention to and be involved in all aspects of the interests of the community, however, the company has a moral responsibility to determine in the Annual Performance Plan social sector programs or agendas needed by the local community, both long and short term.

Jhon Rawls describes justice as fairness. Justice is the result of agreement from fair bargaining. The notion of the principles of justice is agreed upon in a fair ideal situation. This is known as fairness. The principles of fairness are based on an agreement which is called a contract. The description of justice is something ideal, therefore it is born from an ideal situation. Justice according to John Rawls with his concept of democratic equality illustrates that the lucky parties in society must help the less fortunate parties, by sharing or distributing some of their fortunes through a certain mechanism or way. Justice is seen in a horizontal relationship between parties in society.

The theory of justice according to John Rawls emphasizes justice for all people, individual interests cannot be sacrificed for the interests of many people, because this is certainly not fair for parties whose interests are victimized. Everyone has the same rights and freedoms, including the same opportunity to get priority over their interests. The first principle of freedom cannot be replaced by goals for socio-economic interests. It is in this section that there is a fundamental difference between justice according to Jhon Rwals and the utilitarian teachings of Jeremy Bentham.

Utilitarian teachings emphasize efforts to realize the greatest happiness of the greatest number. This is what is described as a form of social justice. Therefore, in utilitarianism it is possible to have certain sacrifices from individuals to get greater benefits for the common good, it can simply be said that in the public interest, personal or individual interests can be sacrificed.

Justice as described by John Rawls is an ideal, so it will be difficult to be realized. However, there are basic principles that can be taken in this case, that justice as fairness can be realized through certain agreements. This shows that there is respect for the values of justice that live in the community. Truth or appropriateness is not determined unilaterally, but involves the parties involved in it. A good mechanism for distributing economic potentials is one that is able to accommodate the interests of all parties fairly.

Richard A. Posner offers justice in the sense of efficiency, so that the value of justice is closer to reality. The management and utilization of the potential of the country's wealth must be efficiently distributed. In Indonesia, the reference that should be the basis for law in regulating and controlling is the constitution of the Republic of Indonesia, in this case the Constitution which functions as a philosophical and controlling foundation in both the economic and social fields, as mandated by Article 33 of the Constitution states that The natural wealth contained therein shall be controlled by the state, including the production branches which are important and dominate the lives of the people, so that they can be used for the greatest prosperity of the people. The national economy, which includes the management of natural wealth and other economic potentials, is organized based on economic democracy with the principles of togetherness, equitable efficiency, sustainability, environmental awareness, independence and by maintaining a balance between progress and national economic unity. All of this has become the basis as well as guidance in establishing further legal rules to organize the national economy. ${ }^{1}$

The national economy is intended to achieve maximum common welfare and this can be achieved if it is done optimally and efficiently. To achieve efficiency in the management of the national economy, regulations and controls are needed which will serve as guidelines in creating technical policies at the operational level. Posner provides a more realistic picture so that it is more applicable, this is what shows a difference when

${ }^{1}$ Rauf, A., Arie, M., Irwansyah, I., (2013). Hakikat Tanggung Jawab Sosial dan Lingkungan perusahaan BUMN Terhadap Stakeholder Di Sulawesi Selatan. Makassar: Pascasarjana Unhas. p. 135-136. 
compared to justice according to John Rawls which is more ideal, however both John Rawls and Posner emphasize that the realization of justice in society needs regulation. It's just that the arrangement according to John Rawls is based on an agreement so that it is more like a social contract, whereas according to the posner, the arrangement is based on legal provisions as stipulated by the government. Justice according to Jhon Rawls emphasizes more on the individual aspect, so that individual interests cannot be sacrificed for the benefit of many people or to maximize the welfare of many people, thus allowing individual sacrifice.

John Rawls's theory of justice states that in order to achieve justice, there is a need for agreement, this shows that the values and aspirations that come from the community through the people's representative council and regional representative council ${ }^{1}$ must be considered. Therefore, the legal provisions formulated by the government must be able to accommodate these values and aspirations. Thus the arrangements from the government can be accepted and more meet the expectations of the community, which in this case will be an ideal basis for realizing justice that is more realistic and can be calculated for the interests of many people, so that it is hoped that social justice can be realized, namely justice for many people. does not ignore individual interests.

If the concept of justice as fairness from Jhon Rawls is combined with Posner's idea of efficiency, a more realistic idea of justice can be generated to realize the maximum welfare value for the masses who are also able to suppress feelings of sacrifice for individuals. The purpose of this idea is in realizing the maximized welfare of many people, it may be necessary to have certain sacrifices from individuals, but individuals can accept these sacrifices, because they are based on agreement, thus arbitrariness can be avoided. Hopefully this kind of idea can become the basis for formulating legal provisions regarding corporate social responsibility. These legal provisions must be able to accommodate the aspirations of all parties in society, so that the implementation of social responsibility can be more accepted and meet the expectations of all parties. This kind of idea is expected to become the basis for formulating legal provisions on social responsibility through a partnership program at SOE companies, where ideally the law only regulates at a more general level, while at a more technical level, space is given for the parties involved. to make agreements in accordance with the situation and conditions faced in their implementation.

The partnership program carried out by SOE companies is to distribute some of the benefits they get, to MSMEs, basically SOE companies are accompanied by sacrifices from the company itself, especially if it is related to the profits that will be booked by the SOE company, however social responsibility. in the form of a partnership program that will reduce the company's profits, but if the interests or aspirations of the company can be accommodated, especially in determining the amount of the budget based on the company's agreement or agreement, then of course the company can accept these sacrifices, so that the distribution of economic potentials can create maximum welfare fairly and equitably for all parties.

\section{The Social Responsibility of the SOE through the Partnership Program is carried out for the Mutual Prosperity.}

So far, the central role in economic development has been placed in the investment process carried out by corporations, both state-owned and private. The corporation has become a social institution that is more dominant than the state, especially in the economic field and in creating jobs for the community.

Article 33 of the 1945 Constitution of the Republic of Indonesia has regulated the management of the economy by the state which aims to achieve the greatest prosperity of the people, not the prosperity of each individual. The economy is structured as a joint effort based on the principle of kinship. The land and water as well as the natural resources contained therein are controlled by the state and used as much as possible for the prosperity of the people, this shows that there is an element of collectivity or togetherness in the country's economic system.

Based on the provisions of Article 33 of the 1945 Constitution of the Republic of Indonesia paragraph (3), the management of the Indonesian national economy is oriented towards efforts to achieve the greatest prosperity of the people. This is in line with the theory of the welfare state. In this theory, the state has a big role in allocating and distributing every resource to meet the basic needs of its citizens.

The theory of the welfare state is a strong foundation for the state to regulate and control every available resource so that it is utilized for the prosperity of the people. The state is responsible for guaranteeing the greatest happiness (welfare) of the best number of their citizens. It is within this framework that the state has a strong basis for regulating the social responsibility of SOE through a partnership scheme for MSMEs. This partnership pattern is interpreted as a form of company participation to jointly participate in realizing community welfare in a fair and equitable manner. This is a form of mutual cooperation in accordance with the cultural roots of the Indonesian nation, thus welfare issues become a shared responsibility, not just the responsibility of the

\footnotetext{
${ }^{1}$ Imran, I., Bakhtiar, H. S., \& Achmad, D. (2020). Legal Standing and Authority of the Regional Representative Council in the Indonesia Constitusional System. Amsir Law Journal, 1(2), 54-60.
} 
government alone.

Even though the idea of a welfare state focuses more on the role of the government to create welfare for its people, in the context of the Indonesian State, the issue of welfare becomes a collective responsibility, this is in accordance with the principle of mutual cooperation which is the culture of the Indonesian nation itself, the practice of mutual cooperation is implemented by the government together with other institutions, people who have the ability to join together and participate in realizing common welfare for all Indonesian people. The participation of SOE in realizing common welfare can be one solution to ease the burden on the government, especially regarding the limited budget for social funds owned by the government, so that the role of the government as a regulator must be able to establish clear rules in carrying out this shared responsibility while still paying attention balance of interests of all parties concerned.

the SOE is a business entity that is wholly or most of the capital owned by the state through direct investment originating from separated state assets. The SOE can be in the form of a Perum (Public Company) or a Limited Liability Company. In a populist economic system, the SOE plays a role in producing the goods or services needed to achieve the greatest possible prosperity for the people. The role of SOE is manifested in business activities in almost all sectors of agriculture, plantation, forestry, mining, manufacturing, finance, post and telecommunications, transportation, electricity, industry, trade and construction.

The SOE is an extension of the government as an institution that is authorized to manage the potentials of strategic value natural resources and production branches deemed important by the state, as stated in the goals and objectives of the establishment of SOE, the government then obliges SOE to carry out social responsibility through a partnership pattern intended for MSMEs, as an effort to create common welfare, so that it can be understood that the social responsibility of SOE is a constitutional task that must be carried out within the framework of advancing the general welfare, so that the implementation of social responsibility from SOE is not only aimed at stakeholders, but for all Indonesian people. This is certainly different from the concept of social responsibility from a liberal capitalist point of view that focuses more on stakeholders in the sense of parties who are affected or influential on the company.

The capitalist-liberal concept of social responsibility in companies is intended to prosper the community, but not for the people as a whole, but is more oriented towards communities around the company's operational areas, or communities affected by company activities, so that the implementation of social and environmental responsibility is more nuanced of reciprocation. Furthermore, the implementation of social responsibility is not in the framework of providing maximum benefits for the prosperity of the people in a just and equitable manner. ${ }^{1}$

In order for the common welfare of all people to be achieved properly, the implementation of social responsibility by SOE companies should be directed at efforts to achieve prosperity for all Indonesian people. This is in accordance with the mandate of the Constitution, which is in line with the context of the welfare state, namely realizing the greatest happiness for the greatest number. The company can be directed to target certain fields or community groups that have not been fully touched by government programs, because there are still many other parties who also have the right to live in prosperity and benefit from natural resources or economic potentials. managed by the company. In addition, the company has an obligation to provide compensation to stakeholders or the community in general as a logical consequence of the results or impacts caused by the company's activities. Even so, the interests of the company must still be considered by looking at the conditions of the company concerned, ideally the social responsibility of SOE through a partnership pattern is carried out for the common interest or the interests of all parties, starting from the company itself, the general public, and even the government. This partnership pattern can be considered as a form of program that can assist the government in realizing welfare for the community at large. The principle of balance of interests of all parties must be used as the basis for its implementation. The principle of balance of interests in the implementation of social responsibility from SOE through a partnership pattern is oriented towards joint welfare efforts, not solely the responsibility of the government. This is what then raises the expression that welfare is a shared responsibility. Therefore, all components of society starting from the government, entrepreneurs and community members themselves must be involved and cooperate with each other to achieve a common goal, namely mutual welfare.

\section{The Social Responsibility of SOE through the Partnership Program as Legal Responsibility}

In order to achieve the goal of national economic development, namely realizing the greatest prosperity of the people, as referred to in the Preamble to the Constitution, namely realizing a just and prosperous society and advancing public welfare, development is carried out which is essentially the development of the whole Indonesian human being and the development of Indonesian society entirely with Pancasila. and the 1945 Constitution of the Republic of Indonesia as the basis and guideline for national development.

Apart from the theory of justice and the theory of the welfare state, the theory of development law is also

${ }^{1}$ Sumardi, J., (2009). Naskah Buku Hukum Perusahaan Transnasional dan Franchise. Accessed on https://core.ac.uk/reader/25487970 
important in implementing the social responsibility of SOE through the Partnership Program for MSMEs, because the legal theory of development is a means of community reform. The definition of law according to this theory does not only view law as a set of rules and principles governing human life in society, but must also include the institutions and processes needed to bring law into reality. Legal thought as a means of renewal is that the existence of order or order in an effort to reform or development is something that is desired or even considered absolute or necessary, and law in the sense of a rule or legal regulation can indeed function as a regulatory tool or a means of development, in the sense of channeling the direction of activities. man in the direction desired by development or renewal.

The theory of development law makes a major contribution in building a system, especially the formation of legislation in the field of social responsibility from SOE through the Partnership Pattern with MSMEs, namely Article 33 of the Constitution as the basic policy that underlies some of the formation of laws, namely, Article 2 paragraph (1), Article 66 paragraph (1) and Article 88 (1) of Law No. 19 of 2003 and Article 74 of Law no. 40 of 2007 which is further elaborated in Government Regulation no. 47 of 2012 and Law No. 20 of 2008.

Social responsibility for SOE as regulated in Law No. 19 of 2003 manifested in the form of the Partnership and Community Development program as regulated in Ministerial Regulation No. 09 / MBU / 2015 concerning the Partnership and Community Development Program for State-Owned Enterprises, which was later amended by PER-03 / MBU-12/2016 concerning Amendments to Regulation of the minister for State-Owned Enterprises Number PER-09 / MBU / 7/2015 concerning Partnership and Environmental Development Programs for StateOwned Enterprises, hereinafter amended again by PER-02 / MBU / 7/2017 concerning the Second Amendment to the Regulation of the Minister for State-Owned Enterprises Number PER-09 / MBU / 07/2015 concerning the Partnership and Community Development Program for State-Owned Enterprises, and was amended again with the issuance of Ministerial Regulation for State-Owned Enterprises No. PER-02 / MBU / 04/2020 concerning the third amendment to the Regulation of the Minister of State-Owned Enterprises Number PER-09 / MBU / 07/2015 concerning the Partnership and Community Development Program for State-Owned Enterprises. Thus, it can be understood that SOE's implementation of the Partnership and Community Development Program is based on the aforementioned rules.

In essence, the partnership program carried out by State-Owned Enterprises is an effort to balance the interests of all parties. This balance of interests can only be achieved through a certain regulatory mechanism, based on the applicable legal provisions by the competent authority, in this case the government. The fulfillment of these interests needs to be balanced or carried out proportionally, through a regulatory mechanism.

If social responsibility in the company is not regulated, there will be a tug of war between the interests of all parties involved. Each particular party will try to defend their respective interests. In addition, each particular party will try to find a position that is more profitable for himself or for his party, so that a balance of interests will be difficult to achieve. It is in this part that the state is present as a regulator by making several legal products that act as balancing the interests of all parties.

Based on the theory of the function of law as put forward by Roscoe Pound, it can be understood that in terms of function, law is an attempt to fulfill, reconcile, adjust demands and requests or interests that vary, even often conflict with one another, which is carried out through the stipulation of law. The law can also provide protection for the interests of each individual through limitation or compromise, so that it can provide greater overall influence. It is in this framework that the law must take the role of realizing harmony and balance of the various interests that exist so that peace can be created in the midst of society.

Justice as fairness, as put forward by Jhon Rawls with his concept of democratic equality, illustrates that the lucky parties in society must help the less fortunate. However, in this context justice cannot work by itself, because although the lucky parties may be aware of this or know that doing social generosity is a good thing, they do not necessarily want to implement it. Therefore, it takes ideas from Roscoe Pound who views that law functions as social engineering, in this case law, can regulate in such a way or even force so that the fulfillment of interests among community groups can run fairly, as expected by all. party.

In order for the law to carry out its functions, the pound has classified interests consisting of: (1) public interests; (2) social interests; (3) individual interests. This is meant that if there is a dispute or conflict of interest in achieving a larger goal, it is necessary to strive for a balance or harmonization of interests. In that conflict of interest, the law will select and recognize the superior interest through the use of power. This will demand victims of interest on one of the parties as a consequence of development.

If John Rawls's theory of justice is connected with Roscoe Pound's theory, then in a conflict of interest, even though the law chooses public interest as the main interest, or social interest over individual interests, in the process it must be pursued that there is a certain mechanism that allows the birth of agreements which is the basis for its implementation, this is intended to prevent arbitrariness in its implementation. Certain mechanisms that allow an agreement to be established must be regulated by law. Thus, the law is expected to play a role in creating ideal conditions in society so that it is able to realize democratic equality between interested parties in order to realize justice as fairness. 
The shift in understanding about social responsibility, which was initially only understood as voluntary moral responsibility, then became mandatory legal responsibility, with the consequence that social responsibility must be carried out based on applicable legal provisions.

If a person is legally responsible for a certain act, then it shows that the person concerned can be subject to sanctions for the opposite act. In other words, if social responsibility is not implemented, the company may be subject to sanctions. Both in the form of compensation and the use of administrative sanctions such as revocation of business licenses. However, the imposition of sanctions must still take into account the conditions of the company. The imposition of sanctions is based on the condition that the interests of other parties are not fulfilled properly, in accordance with applicable legal provisions, resulting in losses. In essence, social responsibility from SOE is not a responsibility that arises solely because of an error, but is a responsibility that has been attached to the company before an incident occurs (ex-ante liability). Responsibility prior to the occurrence of an incident is intended to provide something appropriate to the public based on the prevailing laws or regulations. Meanwhile, ex-post liability is the responsibility to restore the condition of the injured party to its original state, which is presented by the payment of an amount of compensation in accordance with the loss suffered as a form of compensation.

According to the theory of strict liability, is a form of violation / crime which is an absolute liability, in which it does not require an element of error but only requires an act. The company's obligation to carry out corporate social responsibility can be guaranteed by applying the absolute responsibility theory. SOE's social responsibility through the Partnership Program also relates to the welfare of the community. Therefore, it is important to ensure compliance with legal obligations in the form of implementing social responsibility, in addition to being obeyed it is also a deterrent effect as well as an effort to improve company behavior. Social responsibility is closely related to the interests and welfare of the community and has been regulated as a legal mandatory, so it is necessary to impose criminal sanctions so that it becomes a strong force to obey and carry out these obligations, such criminal sanctions can be in the form of fines for corporations that do not carry out the responsibility social company. ${ }^{1}$

\section{The Social Responsibility of SOE through Mandatory Partnership Programs.}

The social responsibility of SOE is an obligation, this is based on Article 2 paragraph (1) Letter e Law No. 19 of 2003 that the purpose and objective of establishing SOE is to actively participate in providing guidance and assistance to economically weak entrepreneurs, cooperatives and the community, besides that it is also regulated in Article 88 paragraph (1) of Law No. 19 of 2003 that SOE can set aside a portion of its net profit for the purposes of fostering small businesses / cooperatives as well as fostering communities around the company. The implementation form of Article 2 paragraph (1) letter e and Article 88 paragraph (1) of Law No. 19 of 2003 regarding the social responsibility of SOE through a partnership pattern which is described by the issuance of Ministerial Regulation No. 09 / MBU / 2015 concerning the Partnership and Community Development Program for State-Owned Enterprises, which was later amended by PER-03 / MBU-12/2016 regarding Amendments to the Regulation of the Minister for State-Owned Enterprises Number PER-09 / MBU / 7/2015 concerning the Partnership and Community Development Program for State-Owned Enterprises, hereinafter amended again with PER-02 / MBU / 7/2017 concerning the Second Amendment to the Regulation of the Minister of Bodies State-Owned Enterprises Number PER-09 / MBU / 07/2015 concerning Partnership and Environmental Development Programs for State-Owned Enterprises, and amended again with the issuance of Regulation of the Minister for State-Owned Enterprises Number PER-02 / MBU / 04/2020 concerning the Third Amendment to Regulation of the Minister for State-Owned Enterprises Number PER-09 / MBU / 07/2015 concerning the Partnership and Community Development Program for State-Owned Enterprises. Article 2 paragraph (1) PER-09 / MBU / 7/2015 concerning the Partnership and Community Development Program for State-Owned Enterprises explains that public companies and companies are required to carry out the Partnership Program and Community Development Program by complying with the provisions stipulated in this regulation. Even though it has been regulated in Law no. 19 of 2003 and its implementing regulations regarding the Partnership Program are an obligation for SOE, it's just Law No. 19 of 2003 and its implementing regulations do not regulate sanctions if social responsibility is not carried out by SOE.

Likewise if it is based on Law no. 40 of 2007, in Chapter V, regulates Social and Environmental Responsibility which only consists of one article, namely article 74 . There are further provisions regarding Social and Environmental Responsibility, according to Article 74 paragraph (2) regulated by a Government Regulation. The description is contained in the eighth paragraph of the General Elucidation, which can be described as:

a) The purpose of Social and Environmental Responsibility is to realize sustainable economic

\footnotetext{
${ }^{1}$ Dewi, D. A. P. S. (2015). Kewajiban Hukum Tanggung Jawab Sosial Perusahaan (Corporate Social Responsibility) Dalam Peraturan PerundangUndangan Di Indonesia. Kumpulan Jurnal Mahasiswa Fakultas Hukum.
} 
development in order to improve the quality of life and the environment that is beneficial to the company itself. Local community and society.

b) Social and Environmental Responsibility aims to support the establishment of a corporate relationship that is harmonious, balanced and in accordance with the environment, values, norms and culture of the local community.

c) In this regard, it is necessary to determine that companies whose business activities are in the field and / or related to natural resources are obliged to carry out Social and Environmental Responsibility.

d) To carry out these obligations, Social and Environmental Responsibility activities must be budgeted and calculated as a company with due observance of appropriateness and reasonableness.

The eighth paragraph of the General Elucidation of Law no. 40 of 2007, closes with a sentence stating that in the event that the company does not carry out social and environmental responsibility, the company concerned will be subject to sanctions in accordance with the provisions of statutory regulations. From this explanation we believe that, Social and Environmental Responsibility as regulated in Law No. 40 of 2007, inspired by a developing view that teaches the company as a company that carries out business activities in the midst of community life, it must take responsibility for the social problems faced by the local community.

This view has given birth to the concept of Corporate Social Responsibility (CSR). The foundation of the CSR view comes from moral values, that the company lives and is in the midst of people's lives. Therefore, the life and smooth running of the company's business activities are very dependent and related to the environment and the community concerned, the company must have concern for the community where the company lives and is located. The company cannot be separated from the responsibility to fulfill the public interest.

Provisions in Law No. 40 of 2007, which regulates social and environmental responsibility only Article 74, and social and environmental responsibility obligations are not borne by all companies, but only limited to companies that carry out business activities in the field of natural resources. What is meant by a company that carries out activities in the field of natural resources according to the elucidation of Article 74 paragraph (1) of Law No. 40 of 2007 is a company that manages and utilizes natural resources, then a company that carries out business activities in fields related to natural resources. What is meant by a company that carries out its business activities related to natural resources, is a company that does not manage and does not utilize natural resources, but its business activities have an impact on the function of natural resource capabilities. Companies that do not carry out business activities in the natural resources sector or which are not related to natural resources are not obliged to carry out social and environmental responsibility.

In order for the implementation of social and environmental responsibility obligations not only as decoration, Article 74 paragraph (2) of Law No. 40 of 2007 ordered the company to budget and take into account social and environmental responsibility as company costs. Thus, when compiling the Annual Work Plan based on article 63 paragraph (1) of Law No. 40 of 2007, in it must contain a budget for social and environmental responsibility for the coming financial year. Implementation of TJSL with due regard to appropriateness and fairness.

According to Article 74 paragraph (3) of Law no. 40 of 2007, a company that does not carry out its social and environmental responsibility obligations, even though it meets the criteria as a company that carries out activities in the field of natural resources or is related to natural resources, is subject to sanctions in accordance with the provisions of laws and regulations. According to the explanation of this article, what is meant by being subjected to sanctions in accordance with statutory regulations is being subjected to all forms of sanctions stipulated in the relevant laws and regulations.

Sanctions as referred to in Article 74 (3) Law No. 40 of 2007 are sanctions based on other laws and regulations. This is related to violations that may be committed by the company in carrying out its activities. These violations include: environmental pollution which is regulated according to the law concerning the environment or related to workers or employees regulated according to the labor law, so that it can be understood that the sanctions referred to in this case are sanctions arising from the existence of element of fault fault from the company because it has violated the law as regulated in this law. The sanctions in question are not directly related to the compensation that should be received by the community in relation to company activities, for example due to noise or dust pollution caused by the traffic of heavy vehicles, or due to factory activities, which in general are all part of the company's activities that cannot be avoided. In addition, community income has decreased because the land or forest that was previously the source of the community's livelihood has been managed by the company, moreover, if it is related to the customary rights of the local community, so it is very possible to have a conflict of interest between the company and the community. Therefore, on the basis of democratic justice and the right of the community to get a decent living and to receive benefits from the products of natural wealth and other economic potentials, the community is obliged to receive compensation, based on the description above, it appears that the sanctions referred to in Article 74 paragraph (3) is not because the company 
does not carry out social and environmental responsibility, but rather because the company has committed a violation of the law as regulated in other laws.

The same thing is also explained by the Assistant Manager at the Main Unit of Generation and Distribution of Sulawesi that the obligations and sanctions as contained in Article 74 paragraph (1) and (3), focus more on the impact caused by the company's activities, so that it is more on creating relationships. harmony between the company and the surrounding community, improving the company's image and trying to prevent the company from violating the law. Therefore, the implementation costs are taken from the budget which are calculated as company costs because they are directly related to the company's activities. The implementation of Social Responsibility is more oriented towards short-term matters, and is limited to parties who are influential and affected by the activities of the company or stakeholders on the basis of interests, both on the company's own interests and the interests of stakeholders. Meanwhile, the implementation of social responsibility as stipulated in Law No. 19 of 2003 and its implementing regulations that the Partnership Program focuses more on community empowerment efforts in the form of assistance and guidance with the intention of making small businesses become resilient and independent, but does not regulate sanctions. The social responsibility activities carried out by SOE are social activities as part of the Public Service function, which are carried out by the company, the bookkeeping is also made separately and the implementation costs are taken from the company's profits, so that the social responsibility carried out by SOE is more like the practice of generosity which is imperative and mandatory. ${ }^{1}$

According to the strict liability theory, it is a form of violation / crime which is absolute responsibility, in which it does not require an element of error but only requires an act. The company's obligation to carry out corporate social responsibility can be guaranteed by applying the strict liability theory. The Social Responsibility of SOE through the Partnership Program also relates to the welfare of the community. Therefore, it is important to ensure compliance with legal obligations in the form of implementing Social Responsibility, in addition to being complied with it is also a deterrent effect as well as an effort to improve company behavior. Social Responsibility is closely related to the interests and welfare of the community and has been regulated as a legal mandatory, so it is necessary to impose criminal sanctions so that it becomes a strong impetus to obey and carry out these obligations, such criminal sanctions can be in the form of fines for corporations that do not carry out the obligations of the corporate social responsibility.

\section{Conclusion}

The essence of social responsibility for state-owned enterprises through the Partnership Program with MSMEs is an effort to balance the interests of all parties. This balance of interests can only be achieved through a certain regulatory mechanism, based on the applicable legal provisions, namely Law No. 40 of 2007 and Law no. 19 of 2003 and Regulation of the Minister for State-Owned Enterprises No. Per-09 / MBU / 07/2015. Fulfillment of interests is carried out proportionally and in a balanced manner through a regulatory mechanism, namely through the use of funds originating from a maximum net profit of $2 \%$ (two percent), in the form of distribution of funds for the Partnership and Development Program, both in the form of loans for business capital as well as guidance and purchase of supporting equipment production which aims to improve the quality of social life for both the company itself, and for MSMEs, which is carried out with the principles of fairness, balance, transparency and sustainability.

\section{References}

Dewi, D. A. P. S. (2015). Kewajiban Hukum Tanggung Jawab Sosial Perusahaan (Corporate Social Responsibility) Dalam Peraturan Perundang-Undangan Di Indonesia. Kumpulan Jurnal Mahasiswa Fakultas Hukum.

Enny Sri Hartati (Peneliti Senior Institute for Developmentof Economics and Finance), 2019, Harian Kompas on 16 Juli 2019.

Fajar, M., \& Setyaningrum, R. B. (2017). Pelaporan Program Kemitraan dan Bina Lingkungan serta Corporate Social Responsibility Badan Usaha Milik Negara. Jurnal Media Hukum, 24(2), 193-206.

Haris, A., Miru, A., Said, N., \& Burhamzah, O. D. (2015). The Effectiveness of the Supervision of Perpetrators of Effort in Producing Quality Products and Its Implications for Consumer Protection. Journal of Humanity, 3(2).

Imran, I., Bakhtiar, H. S., \& Achmad, D. (2020). Legal Standing and Authority of the Regional Representative Council in the Indonesia Constitusional System. Amsir Law Journal, 1(2), 54-60.

Pelupessy, E., Sumardi, J., Marlang, A., \& Miru, A. (2015). Government's Role to Protect the Small Business of Local Communities Legally in Papua. JL Pol'y \& Globalization, 38, 14.

Putra, A. H. (2016). Peran UMKM dalam Pembangunan dan Kesejahteraan Masyarakat Kabupaten Blora. Jurnal

\footnotetext{
${ }^{1}$ Results of an interview with the Assistant Manager at the Main Unit of Generation and Distribution of Sulawesi, December 2020.
} 
Analisa Sosiologi, 5(2).

Rauf, A., Arie, M., Irwansyah, I., (2013). Hakikat Tanggung Jawab Sosial dan Lingkungan perusahaan BUMN Terhadap Stakeholder Di Sulawesi Selatan. Makassar: Pascasarjana Unhas.

Sumardi, J., (2009). Naskah Buku Hukum Perusahaan Transnasional dan Franchise. Diakses pada https://core.ac.uk/reader/25487970

Swasono, S. E. (2002). Sistem Ekonomi Indonesia. Jurnal Ekonomi Rakyat.

http://www.depkop.go.id/data-umkm, accessed on 12 April 2019. 